\title{
The Suitability of Commercially Available Grass Species for Revegetation of Montana Ski Area
}

\author{
MARK J. BEHAN
}

\begin{abstract}
Subalpine areas that were disturbed by ski run construction and then seeded with commercially available grass seed from 2 to more than 10 years ago were examined at 6 Montana ski areas. Species adaptability to subalpine environments was estimated by comparing the species that had become established with those that had been seeded, as well as by presence. Special notice was made of species that had persisted for a decade or longer. Bromus inermis, Festuca ovina, F. rubra, Dactylis glomerata, Agropyron trachycaulum, and $A$. dasystachyum had become successfully established and were persistent in most areas. These species should establish successfully in similar subalpine habitats if seeded for erosion control and revegetation.
\end{abstract}

The usual method of ski run construction involves clear-cutting a swath of trees about $25 \mathrm{~m}$ wide and $2 \mathrm{~km}$ or more in length, generally down the fall line of the slope. Heavy equipment then is often used to clear stumps, remove rock outcrops or smooth out depressions, and thus a mixed subsoil of ten replaces the top soil on the surface. Grasses are desirable for revegetation because they reduce the probability of tree seedling and shrub invasion by competition, provide forage for wildlife, are aesthetically acceptable, and provide a mulch that can cover ground irregularities, thereby allowing the ski area to open with minimal amounts of snow.

Since ski areas are located in areas of high winter precipitation and subsequent heavy spring runoff, revegetation is generally attempted immediately following construction of the ski run in order to reduce erosion and gully formation. Immediate revegetation of denuded areas is important because soil surfaces tend to become compacted over time, reducing the probability of successful seedling establishment without additional soil treatments such as drilling or surface scarification.

The species of grass selected for ski run revegetation should be able to tolerate such adverse conditions as an often acid and low base saturation of former coniferous forest soils, a short growing season, cool days and especially cool nights, frost occurrence in every month and, in Montana, a drought from mid-summer to fall (Brown and Johnston 1979). At elevations of $2,300 \mathrm{~m}$, grass seedlings may grow only $2-4 \mathrm{~cm}$ during the first season even though height growth of the same species growing only $300-600 \mathrm{~m}$ lower in elevation may be several decimeters during the same time. Species that propagate by vegetative methods may have adaptive advantages since the season may be too short in many years to permit viable seed to form (Brown and Johnston 1979).

Steen and Berg (1975) have prepared a bibliography which includes citations of grass species that have been used in alpine and subalpine rehabilitation efforts in the southern Rocky Mountains and in some other areas. Utzig et al. (1978) have listed a number of

\footnotetext{
Author is professor, Department of Botany, University of Montana, Missoula, 59812 ,

This work was supported by Mclntire-Stennis funds allocated to the School of Forestry, University of Montana, Missoula.

Manuscript received December 8, 1980.
}

grass seed mixtures for British Columbian forest habitat zones, including those in which ski areas occur. Brown and Johnston (1978) observed the establishment of several native grasses as well as Agropyron trachycaulum (slender wheatgrass), Dactylis glomerata (orchard grass), Bromus inermis (smooth brome), Phleum pratense (timothy), Poa compressa (Canada bluegrass), Alopecurus pratensis (meadow foxtail), and Festuca arundinacea (tall fescue) for adaptability in the rehabilitation of a high elevation mining disturbance in Montana. Gomm (1974) summarized the results of over 80 seeding trials in nearly every habitat type in Montana, including subalpine forests, by descriptions of many species over several years.

No consistency was detected in the prescriptions for grass seed mixtures for Montana ski areas. It was noted that the seed mixtures applied were often augmented by seed from species in hay bales placed to cover such surface obstructions as rock outcrops. Seed introduced in hay bales or through accidental or natural means provided an important adapted species supplement to those species in the seed mixture being applied.

The purpose of this study was to identify those grasses with commercially available seeds which have been established and persist in the subalpine environments of Montana ski areas. These observations may provide a basis for future recommendations for seed mixtures in similar habitats.

\section{Methods}

The 6-ski areas examined ranged in environment from the relatively low elevation but high precipitation Big Mountain Ski Area in the northwest part of Montana to the high elevation Red Lodge Ski Area in the south-central part of the state (Table 1). Several runs were examined at each ski area by walking their lengths in zig-zag fashion and tabulating occurrence and frequency of grasses encountered. Runs with elevational changes of more than $300 \mathrm{~m}$ or with changing aspect were tabulated separately. Records were obtained, where available, of grasses that had been seeded on those runs examined. These grasses were identified using the terminology of Cronquist et al. (1977). They were ranked into the following qualitative categories of abundance: present if they occurred at all, common if specimens occurred frequently throughout the run being examined, and dominant if the species formed consistent cover over the run or those portions of it that appeared by surface soil characteristics (stoniness, texture, compaction) to provide a suitable seedbed or rooting medium. Elevational ranges, aspect, percent slope, forest habitat type (Pfister et al. 1977), and soil parent materials were determined. Soil pH, texture, cation exchange capacity, 0.3 and 15 bar soil water percentages, organic matter, exchangeable $\mathrm{K}, \mathrm{Ca}$ and $\mathrm{Mg}$, and bicarbonate extractable $P$ were determined at the State Soils Laboratory, Montana State University, Bozeman. Vigor was estimated by height and size of the culms relative to the growth of that species at elevations of $1500 \mathrm{~m}$ or less.

\section{Results and Discussion}

Elevational ranges, aspects, forest habitat types, and average 
Table 1. Environmental characteristics of Montana ski areas.

\begin{tabular}{|c|c|c|c|c|c|}
\hline Area & $\begin{array}{l}\text { Elevation } \\
(\mathrm{m})\end{array}$ & $\begin{array}{c}\text { Slope and } \\
\text { aspect }\end{array}$ & $\begin{array}{l}\text { Annual preci- } \\
\text { tation }\left(\mathrm{cm} \mathrm{yr}^{-1}\right)\end{array}$ & $\begin{array}{l}\text { Soil parent } \\
\text { material }\end{array}$ & Forest habitat types (a) ${ }^{1}$ \\
\hline Big Mountain Whitefish, Mont. & $1460-2060$ & $20-30 \%, \mathrm{~S}$ & $130-180$ & Quartz siltite & ABLA/CLUN - MEFE phase \\
\hline $\begin{array}{l}\text { Snow Bowl } \\
\text { Missoula, Mont. }\end{array}$ & $1520-2190$ & $30-50 \%, \mathrm{~S} ., \mathrm{W}$ & $75-100$ & $\begin{array}{l}\text { Belt } \\
\text { argillite }\end{array}$ & $\begin{array}{l}\text { ABLA/XETA - VAGL phase at lower } \\
\text { elevations, ABLA/MEFE at mid- } \\
\text { elevations, and ABLA/LUHI at upper } \\
\text { elevations }\end{array}$ \\
\hline $\begin{array}{l}\text { Discovery Basin } \\
\text { Georgeto'vn, Lake, Mont. }\end{array}$ & $2070-2580$ & $25 \%, \mathrm{~S}$ & $75-100$ & $\begin{array}{l}\text { Belt } \\
\text { argillite }\end{array}$ & ABLA/XETE - VAGL phase \\
\hline $\begin{array}{l}\text { Bridger Bowl } \\
\text { Bozeman, Mont. }\end{array}$ & $1900-2400$ & $25-45 \%, \mathrm{E}$ & $100-130$ & Limestone & $\begin{array}{l}\text { ABLA/CARU at lower elevations and } \\
\text { PIAL/ABLA at higher elevations }\end{array}$ \\
\hline $\begin{array}{l}\text { Showdown } \\
\text { Neihart. Mont. }\end{array}$ & $2130-2450$ & $30 \%, \mathrm{E}$ to N.E. & $75-100$ & $\begin{array}{l}\text { Volcanic } \\
\text { biotite }\end{array}$ & $\begin{array}{l}\text { ABLA/VASC at lower elevation, PIAL } \\
\text { at higher elevation }\end{array}$ \\
\hline $\begin{array}{l}\text { Red Lodge } \\
\text { Red Lodge, Mont. }\end{array}$ & $2250-2750$ & $24-45 \%, \wedge$ & $75-100$ & $\begin{array}{l}\text { Granite } \\
\text { Eneiss }\end{array}$ & $\begin{array}{l}\text { ABLA/VASC - VASC phase at lower } \\
\text { ABLA/PIAL/VASC at higher elevations }\end{array}$ \\
\hline
\end{tabular}

slope percentages are given in Table 1. Additional climatic and biological information related to the forest habitat types has been described by Pfister et al. (1977).

No relationship could be detected between the species'presence or vigor of the grasses growing in an area and the soil characteristics determined. This may be due to a relatively high potential fertility of the soils examined for all nutrients, with the possible exception of nitrogen. The textures of these mountain soils ranged from sandy loams through clay loam, while $\mathrm{pH}$ ranged from 5.1 to 7.9, with half the samples in the range of $\mathrm{pH}$ 5.6-6.5. The lowest cation exchange capacity (CEC) found was $9.4 \mathrm{meq} 100 \mathrm{~g}$ and 13 of 17 samples measured $15 \mathrm{meg} 100 \mathrm{~g}$ or more.

The lowest exchangeable $K$ found was $160 \mathrm{pp} 2 \mathrm{~m}$, which should be adequate if these grasses have requirements similar to those in dry lands (Wilson and Wambolt 1973). Although some soil properties reflected the parent materials upon which they were found (e.g., $\mathrm{pH}$, exchangeable $\mathrm{Ca}$ and $\mathrm{Mg}$ were highest on the limestone), the overriding factor determining plant success or failure seemed to be associated far more with climate (i.e., elevation and aspect) and the species selected for seeding.

Smooth brome, orchard grass, timothy, and slender wheatgrass generally established good stand s under the variety of environmental conditions represented by this cross-section of subalpine habi- tat within a few years after having been seeded. Intermediate wheatgrass, meadow foxtail, crested wheatgrass, and mountain brome were seeded in a few areas but did not develop in abundance within the first few years after seeding.

The areas with the highest elevations, least favorable aspect, and least fertile soils were the upper portions of Snow Bowl, Showdown, and Red Lodge ski areas. The species that we re most abundant under these harsh environmental conditions were smooth brome, timothy, red fescue, and hard fescue.

Three of the areas had been seeded at least 15 years ago and therefore offered the opportunity to determine the persistence of the species originally planted. At Big Mountain, a run seeded in 1961, still contained significant stands of timothy, tall fescue, orchard grass, and smooth brome. A run seeded at Snow Bowl in 1964 had a well-established stand dominated by smooth brome, slender wheatgrass, timothy, and hard fescue (it was reported that intermedite wheatgrass, not slender wheatgrass, was sown but it was not found and thus an error in the report is likely). At Showdown, an area seeded with an unknown mixture over 20 years ago was dominated by smooth brome, timothy, and slender wheatgrass. Kentucky bluegrass, red fescue, Idaho fescue and thickspike wheatgrass also provided noticeable cover. The run at Big Mountain is mowed annually, but the other areas are not. All of these

Table 2. Grasses growing on Montana ski areas.!

\begin{tabular}{|c|c|c|c|c|c|c|}
\hline Species² & $\begin{array}{l}\text { Big } \\
\text { Mountain }\end{array}$ & Snow Bowl & $\begin{array}{l}\text { Discovery } \\
\text { Basin }\end{array}$ & $\begin{array}{l}\text { 3ridger } \\
\text { Bowl }\end{array}$ & Showdown & Red Lodge \\
\hline Canida bluegrass (Poa compressa) & & & & & & + \\
\hline Kentucky bluegrass ( $P$. pratensis) & & & $+s^{3}$ & + & + & + \\
\hline Mountain brome (Bromus carinatus) & & & & $+s$ & & $\mathbf{s}$ \\
\hline Smoo:h brome (B. inermis) & $++s$ & $+t-s$ & $+++s$ & ++ & $+++s$ & +++ \\
\hline Tall fescie (Festuca arundinacea) & $++t s$ & $\mathbf{S}$ & & & & \\
\hline Idaho fescue ( $F$. idahoensis) & & & & & + & $++t$ \\
\hline Meadow fescue ( $F$. pratensis) & & & & + & & \\
\hline Hard fesiue ( $F$. ovina) & & $+++s$ & & $\mathbf{s}$ & 1 & $++s$ \\
\hline Red fescue ( $F$. rubra) & + & + & & & + & $+++s$ \\
\hline Meadow foxtail (Alopecurus pratensis) & & & & $s$ & & \\
\hline Orchard grass (Dactylis glomerata) & $+++s$ & & $+++s$ & +++ & $+\mathrm{s}$ & + \\
\hline Timothy (ohleum pratense) & $++s$ & $+-r+s$ & $+++s$ & $+++s$ & $+++s$ & $++t$ \\
\hline Crested wineatgrass (Agropyron cristatum) & $+s$ & & $+s$ & & & \\
\hline Intermediate wheatgrass ( $A$. intermedium) & & $\mathbf{s}$ & $+\mathrm{s}$ & $\mathrm{S}$ & & \\
\hline Slender wheatgrass (A. trachycaulum) & & & $+\mathrm{s}$ & $+++s$ & + & ++ \\
\hline Thickspike wheatgrass (A. dasystachyum) & & +++ & & + & + & ++ \\
\hline
\end{tabular}

The ski areas are listed in estimated order of increasing environmental stress from left to rig.rt (Table 1).

Scientific names follow those of Cronquist et al. (1977).

is $=$ reported 1 ) have been seeded, $t=$ present,$++=$ common, $++t=$ dominant. 
older grass stands appear to be providing sufficient competition to reduce the rate of invasion of trees and shrubs, although the mowing at Big Mountain probably contributes to this as well.

Several species of grasses with commercially available seed have become successfully established without known seeding. These volunteers include thickspike wheatgrass (which occurred in several areas) as well as red and Idaho fescue. Canada bluegrass and smooth brome are important in the high elevation cover at Red Canada bluegrass may be successful in certain conditions; these are most prominent in and near hay bales that have been placed as padding over terrain obstacles.

The absence of a particular species does not necessarily mean that it might not have been successful but rather that it may have been seeded only occasionally or never at all in the a reas examined. In any case, smooth brome, orchard grass, timothy, slender and thickspike wheatgrasses, red, hard and Idaho fescues, Kentucky and Canada bluegrasses all appear to offer a high potential for successful establishment in the subalpine environments of Montana.

The results of this study differ somewhat from those of Brown et al. (1978) who seeded and transplanted native and introduced species into a Montana alpine area disturbed by mining activity. Their study area was near the Red Lodge ski area that l examined, but about $250 \mathrm{~m}$ higher in elevation and, although both areas had similar soil parent material, the soil in their study had been altered by acidic mine waste water contaminated with heavy metals. Brown's study found smooth brome and orchard grass to be poorly adapted for alpine revegetation under these conditions, whereas I found these species to be quite successful in the subalpine areas examined. Both studies found timothy, slender wheatgrass, and Canada bluegrass adapted in these zones, whereas Brown et al. (1978) also found meadow foxtail successful.

Welin (1974) found smooth brome, orchard grass, and perennial wildrye (Lolium perenne) successful in the revegetation of a Colorado ski area, but not Kentucky bluegrass. Berg (1974) notes that both meadow and Garrison creeping foxtail (Alopecurus arundinaceus), as well as smooth brome, persist in the subalpine zone of Colorado, but that timothy, slender wheatgrass, tall fescue, orchard grass, and rye grass usually establish but do not persist. Several of these grasses are persistent in Montana ski areas. Berg (1974) also notes that red and hard fescue, Kentucky bluegrass and Canada bluegrass may be successful in certain conditions; these species are also found in most of the Montana ski areas where they have been seeded. I have no explanation for the species'differences observed, but there are significant differences in altitude, latitude, and summer precipitation and diurnal temperature patterns between the Colorado and Montana areas which were examined.

Based upon these observations, a grass mixture composed of $30 \%$ smooth brome, $10 \%$ orchard grass, $6 \%$ timothy, $20 \%$ slender wheatgrass, $18 \%$ thickspike wheatgrass, $5 \%$ red fescue, $5 \%$ hard fescue, 2\% Canada bluegrass, $2 \%$ Kentucky bluegrass, and 2\% innoculated white or red clover (Trifolium repens or $T$. pratense) should be successful in similar subalpine habitats. The mixture provides approximately equal quantities of seed, but if one species were difficult to obtain it could be deleted and the a mounts of the others increased accordingly. I have seen both clovers established on ski runs, but white clover was noticed at the highest elevations. Where varieties are available, those recommended for the shortest or coldest growing seasons will probably prosper best (e.g., Manchar smooth brome). Current recommendations for rates of application range from 20 to $40 \mathrm{~kg} / \mathrm{ha}$, and these as well as other planting and initial establishment techniques for high altitude grass revegetation have been described by Brown and Johnston (1979), Welin (1974), Hull (1974), and Plummer et al. (1968).

\section{Literature Cited}

Berg, W.A. 1974. Grasses and legumes for revegetation of disturbed subalpine areas. p. 31-35 In: W.A. Berg et al., (eds.) Proc. of a workshop on revegetation of high-altitude disturbed lands. Environmental Res. Center Information Series No. 10. Colorado State Univ., Fort Collins.

Brown, R.W., and R.S. Johnston. 1978. Rehabilitation of a high elevation mine disturbance. p. 116-130. In: S.T. Kenney, (ed.) Proceedings: High Altitude Workshop No. 3. Environmental Res. Center Information Series No. 28. Colorado State Univ., Fort Collins.

Brown, R.W., and R.S. Johnston. 1979. Revegetation of disturbed alpine rangelands. p. 76-94 In: D.A. Johnson, (ed.) Special management needs of alpine ecosystems. Range Sci. Ser. No. 5. Soc. Range Manage., Denver, Colo.

Cronquist, A. A.H. Holmgren, N.H. Holmgren, J.L. Reveal, and P.K. Holmgren. 1977. Intermountain Flora. Vol. 6, The monoctyledons. Columbia Univ. Press, N.Y.

Gomm, F.B. 1974. Forage species for the northern intermountain region. A summary of seeding trials. USDA, Agr. Res. Serv. Tech. Bull. 1479. Logan, Utah.

Hull, A.C., Jr. 1974. Seedling emergence and survival from different seasons and rates of seeding mountain rangelands. J. Range Manage. 27:302-304.

Prister, R.D., B.L. Kovalchik, S.F. Arno, and R.C. Presby. 1977. Forest habitat types of Montana. USDA Forest Service Gen. Tech. Rep. INT 34.

Plummer, A.P., D.R. Christenson, and S.B. Monsen. 1968. Restoring biggame range in Utah. Utah Division of Fish and Game Pub. 68-3. Ephraim.

Steen, 0., and W.A. Berg. 1975. Bibliography pertinent to disturbance and rehabilitation of alpine and subalpine lands in the southern Rocky Mountains. Environmental Res. Center Information Series No. 14. Colorado State Univ., Fort Collins.

Utzig, G., D. MacDonald, and P. Comeau. 1978. Ecological classification for the Nelson Forest District. British Columbia Forest Service, Nelson, B.C.

Welln, C. 1974. Cultural problems and approaches in a ski area. p 64-70 In: W.A. Berg et al., (eds.) Proceedings of a workshop on revegetation of high-altitude disturbed lands. Environmental Res. Center Information Series No. 10. Environmental Res. Center, Colorado State Univ., Fort Collins.

Wilson, R., and C. Wambolt. 1973. Native range fertilizer guide. Coop. Ext. Serv., Montana State Univ., Bozeman. 